\title{
Antimicrobial peptides and bacteriocins: alternatives to traditional antibiotics
}

\author{
Yongming Sang and Frank Blecha* \\ Department of Anatomy and Physiology, Kansas State University, Manhattan, KS 66506, USA
}

Received 26 August 2008; Accepted 19 September 2008; First published online 5 November 2008

\begin{abstract}
Antimicrobial peptides (AMPs) are ubiquitous, gene-encoded natural antibiotics that have gained recent attention in the search for new antimicrobials to combat infectious disease. In multicellular organisms, AMPs, such as defensins and cathelicidins, provide a coordinated protective response against infection and are a principal component of innate immunity in vertebrates. In unicellular organisms, AMPs, such as bacteriocins, function to suppress competitor species. Because many AMPs kill bacteria by disruption of membrane integrity and are thus thought to be less likely to induce resistance, AMPs are being extensively evaluated as novel antimicrobial drugs. This review summarizes and discusses the antibiotic properties of AMPs highlighting their potential as alternatives to conventional antibiotics.
\end{abstract}

Keywords: antibiotics, antimicrobial peptides, bacteriocin, animal health

\section{Introduction}

\section{Antimicrobial peptides (AMPs): ubiquitous natural antibiotics}

Small biological molecules $(<10 \mathrm{kDa})$ with direct antimicrobial activity, including enzymatically synthesized compounds and ribosomal-synthesized AMPs, provide effective microbial defense for all organisms from bacteria to mammals (Beutler, 2004; Hancock and Sahl, 2006). The discovery and development of conventional antibiotics, which are primarily based on bacteria- or fungi-generated antimicrobial compounds, have led to dramatic improvements in the ability to treat infectious diseases and significant increases in food animal production. Unquestionably, antibiotics represent one of the major scientific and medical advances of the 20th century (Gordon et al., 2005; McPhee and Hancock, 2005). Although antibiotic therapy is still the first choice to combat microbial infections in humans and animals, the prevalence of bacterial resistance to conventional antibiotics is a

*Corresponding author. E-mail: blecha@vet.k-state.edu growing public health concern. This has driven the search for new antimicrobials that are broadly effective and less likely to induce antimicrobial resistance.

Natural gene-encoded AMPs are a diverse group of innate immune molecules present in all organisms. Mature AMPs generally contain 12-100 amino acid residues, possess a net positive charge and an amphipathic structure that facilitates interaction with negatively charged microbial membranes or other cellular targets (Yeaman and Yount, 2007; Linde et al., 2008; Sang and Blecha, 2008). A list of the general properties of AMPs, including primary structural properties and antimicrobial activities, is presented in Table 1. Compared with conventional antibiotics, which are generally active against bacteria or fungi, AMPs often exert activity against a broad spectrum of micro-organisms including bacteria, fungi, parasites, enveloped viruses and even some cancer cells. In addition, unlike conventional antibiotics, which generally target a metabolic enzyme and may selectively induce resistance in micro-organisms, AMPs kill microbes mainly by membrane-targeting pore-forming mechanisms (Table 2), a mechanism that is inherently more difficult for microbes to circumvent by developing resistance (Boman, 2003; Hancock and Sahl, 2006). AMPs have been isolated from most life forms and include bacteriocins, 
Table 1. Examples and general properties of AMPs

\begin{tabular}{|c|c|c|c|c|}
\hline Organism & Class/subclass & Examples & Main structural properties & Antimicrobial activity \\
\hline $\mathrm{LAB}^{1}$ & $\begin{array}{r}\text { Class I and II } \\
\text { bacteriocins }\end{array}$ & $\begin{array}{l}\text { Lantibiotics } \\
\text { Class I: nisin, mersacidin; } \\
\text { non-lantibiotics. } \\
\text { Class II: pediocin, PA1, } \\
\text { enterocin AS48 }\end{array}$ & $\begin{array}{l}\text { Class I: extensive } \\
\text { post-translational residue } \\
\text { modification. Either elongated } \\
\text { cationic or globular } \\
\text { conformation. Class II: very } \\
\text { diverse group. Pediocin-like } \\
\text { members conforming } \beta \text {-sheet } \\
\text { structures and a C-terminal } \\
\alpha \text {-helix }\end{array}$ & $\begin{array}{l}\text { Nanomolar range, } \\
\text { active against } \\
\text { closely related or } \\
\text { broad-spectrum } \\
\text { Gram-positive } \\
\text { bacteria }\end{array}$ \\
\hline $\begin{array}{l}\text { Other } \\
\text { bacteria } \\
\text { (e.g. E. coli })^{2}\end{array}$ & Bacteriocins & Colicins, microcins & $\alpha$-Helix-rich globular structure & $\begin{array}{l}\text { Nanomolar range, } \\
\text { active against } \\
\text { Enterobacteriaceae }\end{array}$ \\
\hline Fungi $i^{3}$ & Fungal defensins & Plectasin & $\begin{array}{l}\text { Cysteine-rich, containing two } \\
\text { antiparallel } \beta \text {-sheets and an } \\
\alpha \text {-helix }\end{array}$ & $\begin{array}{l}\text { MIC: } 1-35 \mu \mathrm{g} / \mathrm{ml} \text { for } \\
\text { multiple antibiotic- } \\
\text { resistant Gram- } \\
\text { positive bacteria }\end{array}$ \\
\hline Plants $^{4}$ & Plant defensins & Ib-AMP1-4 and cyclotides & $\begin{array}{l}\text { Cysteine-rich, containing } \\
\text { antiparallel } \beta \text {-sheets, and } \\
\text { cyclotides with cyclic } \\
\text { backbone and cysteine knot }\end{array}$ & $\begin{array}{l}\text { Micromolar range: } \\
\text { antifungal (Ib- } \\
\text { AMPs), anti-HIV, } \\
\text { anti-parasites } \\
\text { (cyclotides) }\end{array}$ \\
\hline $\begin{array}{l}\text { Insects/ } \\
\text { amphibians }^{5}\end{array}$ & $\begin{array}{l}\text { Insect/ } \\
\text { amphibian } \\
\text { cationic } \\
\text { peptides }\end{array}$ & $\begin{array}{l}\text { Cecropin A, mellitin, } \\
\text { magainins, temporins }\end{array}$ & $\begin{array}{l}\text { High basic residue content, } \\
\text { form } \alpha \text {-helix containing } \\
\text { structures in membrane }\end{array}$ & $\begin{array}{l}\text { Micromolar range } \\
\text { active against } \\
\text { multidrug-resistant } \\
\text { bacteria }\end{array}$ \\
\hline $\begin{array}{l}\text { Arachnida/ } \\
\text { vertebrates }^{6}\end{array}$ & $\begin{array}{l}\text { Venom toxins/ } \\
\beta \text {-defensins }\end{array}$ & $\begin{array}{l}\text { Defensin-like toxins (DLTs) } \\
\text { in venom, and } \beta \text {-defensins }\end{array}$ & $\begin{array}{l}\beta \text {-Sheets and disulfide bonds } \\
\text { form into } \beta \text {-hairpins, } \\
\text { and D-amino acid } \\
\text { post-translational } \\
\text { modification in DLTs }\end{array}$ & $\begin{array}{l}\text { Micromolar range, } \\
\text { active against } \\
\text { multidrug-resistant } \\
\text { bacteria mostly in a } \\
\text { salt-dependent } \\
\text { manner }\end{array}$ \\
\hline Mammals $^{7}$ & $\begin{array}{l}\alpha \text {-Defensins } \\
\theta \text {-Defensins } \\
\beta \text {-Defensins }\end{array}$ & $\begin{array}{l}\text { Human neutrophil defensins, } \\
\text { enteric and epithelial } \\
\text { defensins }\end{array}$ & $\begin{array}{l}\beta \text {-Sheets and disulfide bonds } \\
\text { form into } \beta \text {-hairpins }\end{array}$ & $\begin{array}{l}\text { Micromolar range } \\
\text { active against } \\
\text { multidrug-resistant } \\
\text { bacteria, and fungi } \\
\text { and viruses }\end{array}$ \\
\hline $\begin{array}{l}\text { Higher } \\
\text { vertebrates }\end{array}$ & Cathelicidins & $\begin{array}{l}\text { Human LL-37, porcine } \\
\text { PR-39, bovine indolicidin }\end{array}$ & $\begin{array}{l}\text { Contain a cathelin leader } \\
\text { sequence with an } \\
\text { amphipathic cationic } \\
\text { mature peptide }\end{array}$ & $\begin{array}{l}\text { Micromolar range } \\
\text { active against } \\
\text { multidrug-resistant } \\
\text { bacteria, and fungi } \\
\text { and viruses }\end{array}$ \\
\hline Humans $^{9}$ & Others & $\begin{array}{l}\text { Lactoferricin, and } \\
\text { antimicrobial domain of } \\
\text { lysozyme }\end{array}$ & $\begin{array}{l}\text { Derived anionic/cationic } \\
\text { antimicrobial fragments } \\
\text { from lactoferrin, casein } \\
\text { and lysozyme }\end{array}$ & $\begin{array}{l}\text { Micromolar range } \\
\text { active against } \\
\text { multidrug-resistant } \\
\text { bacteria }\end{array}$ \\
\hline
\end{tabular}

${ }^{1}$ Willey et al., 2007; Field et al., 2008.

${ }^{2}$ Duquesne et al., 2007; Nes et al., 2007.

${ }^{3}$ Mygind et al., 2005.

${ }^{4}$ Colgrave et al., 2008; Ireland et al., 2008; Marcos et al., 2008.

${ }^{5}$ Bechinger, 1997; Giacometti et al., 2003.

${ }^{6}$ Yeaman and Yount, 2007; Warren et al., 2008.

${ }^{7}$ Selsted and Ouellette, 2005; Lehrer, 2007.

${ }^{8}$ Zanetti, 2005.

${ }^{9}$ Brogden, 2005.

fungal peptide antibiotics, plant thionins and defensins, insect defensins and cecropins, amphibian magainins and temporins, as well as defensins and cathelicidins from higher vertebrates (McPhee and Hancock, 2005; Yeaman and Yount, 2007). This review will summarize and discuss the antibiotic properties of AMPs with the aim of highlighting their potential as alternatives to conventional antibiotics. 
Table 2. Characteristics and applications of biological antimicrobials

\begin{tabular}{ll}
\hline & $\begin{array}{l}\text { Conventional antibiotics } \\
\text { Enzymatically synthesized compounds }\end{array}$
\end{tabular}

${ }^{1}$ Structure information for penicillin is from the public domain (http://www.hopkins-abxguide.org/). Structures of canine $\beta$-defensin-1 and cathelicidin were adapted from our previous work (Sang et al., 2005; Sang et al., 2007).

\section{Bacteriocins: bacterial AMPs}

Bacteriocins are bacterially produced, small, heatstable peptides that bacteria use to compete against other bacteria of the same species (narrow spectrum) or against bacteria of other genera (broad spectrum) (Cotter et al., 2005). One or several bacteriocins have been identified or are believed to exist in every species of bacteria and archaea (Cotter et al., 2005; Willey and van der Donk, 2007). A current bacteriocin database (Hammami et al., 2007; http://www.cck.rnu.tn/pfba/bactibase/main.php) lists 145 entries including 39 lanthionine-containing bacteriocins (Class I), 40 non-lanthionine-containing bacteriocins (Class II) and other unclassified entries, likely bacteriolysins (Cotter et al., 2005; Willey and van der Donk, 2007). Class I bacteriocins are small peptides (18-39 residues) and are commonly called lantibiotics because of the lanthionine or $\beta$-methyllanthionine residues that they contain. These unusual residues are formed during post-translational modification and enzymatically crosslink a dehydrated serine/threonine to a neighboring cysteine, resulting in intramolecular covalent bridges (Cotter et al., 2005; Willey and van der Donk, 2007). In contrast, Class II bacteriocins constitute a very diverse group and are not subject to this extensive posttranslational modification. Class III bacteriolysins are large, heat-labile proteins that catalyze the hydrolysis of bacterial cell walls resulting in autolysis of targeted bacteria. The majority of Class I and Class II bacteriocins are active in the nanomolar range against Gram-positive bacteria in closely related species or in a broad-spectrum manner for many species.

The most promising bacteriocins in development as antibiotics are those produced by lactic acid bacteria
(LAB) with the core genera including Lactobacillus, Lactococcus, Leuconostoc, Pediococcus and Streptococcus. Because of the long history of using LAB in the processing of fermented foods, the antimicrobial and safety information for LAB in food preservation is widely accepted. In addition, LAB are used extensively as probiotics in food processing and preservation (De Vuyst and Leroy, 2007; Sit and Vederas, 2008), and LAB-derived bacteriocins will likely enter the working pharmacopeia as oral or gastrointestinal antibiotics (Rossi et al., 2008). Examples of LAB-derived bacteriocins include nisin, mersacidin, lacticin 481 and lacticin 3147. Among these, nisin has been approved for commercial use in some food processing applications and as an anti-infective for bovine mastitis (Cotter et al., 2005; Dufour et al., 2007), and mersacidin has been evaluated in preclinical tests to treat Gram-positive infections (Hancock and Sahl, 2006). Lacticin 3147, a two-peptide lantibiotic, has shown promise in preventing mastitis infections (Crispie et al., 2005) and as a food preservative (Gardiner et al., 2007). Importantly, several bacteriocins, including lacticin 3147 , mersacidin and leucocin A, display potent activity against antibiotic-resistant bacterial strains such as vancomycinresistant enterococci (VRE) and methicillin-resistant Staphylococcus aureus (MRSA) (Kruszewska et al., 2004; Sit and Vederas, 2008). In addition to food-introduced $\mathrm{LAB}$, gastrointestinal commensal LAB (enterococci and streptococci) and microflora of the family Enterobacteriaceae produce a large panel of bacteriocins, such as enterocins, salivaricins, colicins and microcins. These bacteriocins have significant potential for probiotic or antibiotic use after suitable biotechnological modifications are developed (Duquesne et al., 2007; Nes et al., 2007). 


\section{Fungal AMPs}

The most widely used and historic antibiotic to date, penicillin, is from the fungus Penicillium chrysogenum, previously named Penicillium notatum. In addition, many peptide antimicrobials are produced by fungi. For example, soil-fungi peptide antibiotics named peptaibols (small peptides usually containing $\alpha$-aminoisobutyric acid and a C-terminal alcohol) have potent antibacterial and antifungal properties (Duclohier, 2007). The antimicrobial properties of peptaibols derive from their amphipathic, helical structure that facilitates lytic pore formation in membranes. Although peptaibols are peptide antibiotics they are not gene-encoded, ribosomal-produced AMPs; instead they use a multi-enzyme, non-ribosomal peptide sythetase complex (peptaibol synthetase) for their biosynthesis (Leitgeb et al., 2007). Hundreds of peptaibol sequences are compiled in the Peptaibol Database (http://www.cryst.bbk.ac.uk/peptaibol/home.shtml).

Fungal genomes also encode abundant cysteine-rich AMPs consisting of $\alpha$-helix and $\beta$-sheet structures, collectively called defensin-like peptides (Zhu, 2008). Plectasin is the first identified fungal defensin and is active against antibiotic-resistant strains of Streptococcus pneumoniae with efficacy in treating peritonitis and pneumonia in mice (Mygind et al., 2005) (Table 1). Bioinformatics analysis of fungal genomes reveals six families of fungal defensin-like peptides, among which three families are ancestral to defensin molecules from plants, insects and invertebrates (Zhu, 2008). Indeed, evolutionarily, cysteine-rich defensin-like peptides have been suggested to be the most diverse group of AMPs existing in all cellular organisms (Yeaman and Yount, 2007; Zhu, 2008).

\section{Plant AMPs}

It has been estimated that there are about 300 genes encoding defensins in plants (Silverstein et al., 2005; Thevissen et al., 2007). Although direct antimicrobial activity of most plant defensins against animal pathogens has not been reported, four cysteine-rich plant AMPs and their synthetic analogues are potent against bacterial and fungal infections. These AMPs were isolated from seeds of Impatiens balsamina, an herb with a long history of use among Asian people to treat infectious diseases (Thevissen et al., 2007; Marcos et al., 2008). Another fascinating subgroup of plant AMPs are cyclotides characterized by a cyclic backbone and knotted disulfide bonds resulting from cyclization. Plant cyclotides were recently shown to be highly active against HIVinfected cells (Ireland et al., 2008) and to significantly suppress the development of gastrointestinal nematode parasites in livestock (Barbeta et al., 2008; Colgrave et al., 2008).

\section{Animal AMPs}

Most animals possess defensins or defensin-like peptides. Indeed defensin-like peptides are present in venom toxins from arthropod and reptile species such as scorpions and snakes (Whittington et al., 2008), and genome analysis of the platypus suggests that defensinlike peptides are an evolutionary signature (Warren et al., 2008; Whittington et al., 2008). Mammals possess the most diverse groups of defensins. Three subgroups of mammalian defensins, $\alpha$-, $\beta$ - and $\theta$-defensins, have been classified based on the differential connections of their three disulfide bridges (Ganz, 2003; Selsted and Ouellette, 2005). Defensins have evolved in mammals with $\alpha$ - and $\theta$ defensins only appearing in species later than glires and some primate clades (Selsted and Ouellette, 2005; Lehrer, 2007; Lynn and Bradley, 2007; Sang and Blecha, 2008).

In addition to cysteine-rich AMPs, there are other prominent subgroups of AMPs in animals characterized on the basis of primary or secondary peptide structure (Brogden, 2005). One subgroup is characterized by an abundant number of cationic peptides containing basic and/or hydrophobic residues at a high ratio and many of them conform into $\alpha$-helical structures in membranemimetic environments. Examples of these subgroups include mammalian cathelicidins, amphibian magainins and maximins, and insect cecropins. Some members of this subgroup, such as cathelicidins, are rich in certain residues such as proline (e.g. porcine PR-39), phenylalanine (e.g. porcine prophenins) and tryptophan (e.g. bovine indolicidin), which may contribute to their 'multi-hitting' model of antimicrobial responses (McPhee and Hancock, 2005; Hancock and Sahl, 2006; Hale and Hancock, 2007) (Fig. 1). The second subgroup of AMPs includes antimicrobial fragments derived from large proteins such as lactoferricin from lactoferrin and the antimicrobial domain of lysozyme (Brogden, 2005) (Table 1). Potent activity against a broad spectrum of micro-organisms including bacteria, fungi, enveloped viruses and tumor cells has been observed in members of these animal AMPs (Brogden, 2005) plus multiple roles with respect to immunoregulation and cell signaling (Hancock and Sahl, 2006; Zaiou, 2007). These examples illustrate the diversity of AMPs and suggest that they may be a rich source for future antibiotic design and drug development. Indeed, multiple AMPs or analogues are in development for antimicrobial and immunoregulatory therapies (Gordon et al., 2005; McPhee and Hancock, 2005; Hancock and Sahl, 2006).

\section{AMPs as natural antibiotics: antimicrobial activity, mechanism of action and current status in development}

Similar to traditional antibiotics, most AMPs are highly active against bacteria and fungi. However, many AMPs, 


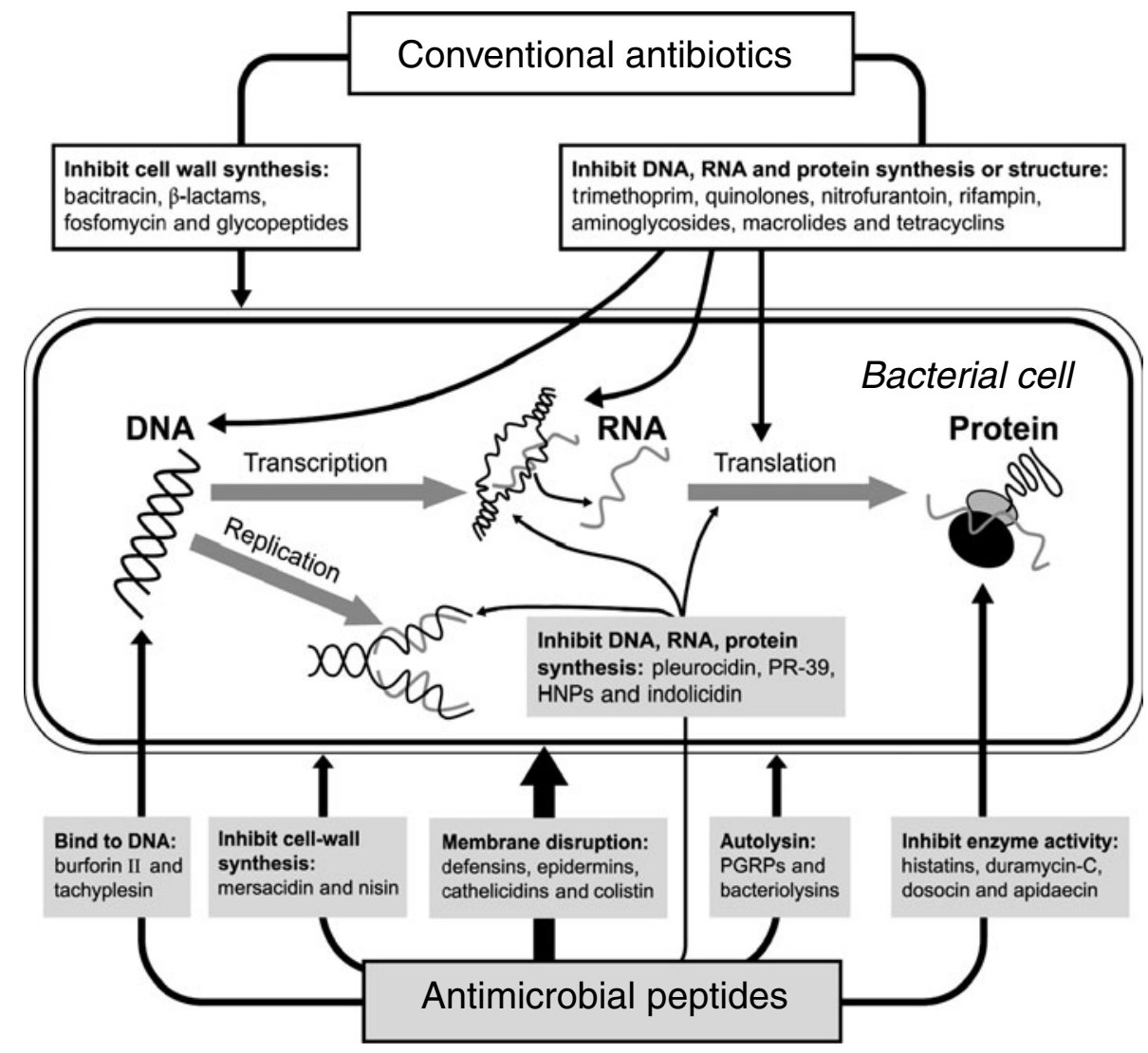

Fig. 1. Mechanisms of action of conventional antibiotics and AMPs. Bactericidal mechanisms of AMPs are illustrated with an emphasis on the propensity to membrane disruption. AMP-related aspects were adapted with permission from Macmillan Publishers: Nature Reviews: Microbiology (Brogden, 2005) and Nature Biotechnology (Hancock and Sahl, 2006). Conventional antibiotic information was adapted from a public domain (http://www.hopkins-abxguide.org/).

including plant cyclotides, and animal defensins and cathelicidins, also possess antiviral or anti-parasite activity (Table 1). Generally, bacteriocins are extremely active against related Gram-positive bacteria or Enterobacteriaceae with minimal inhibitory concentration (MIC) in the nanomolar range. Several bacteria that produce bacteriocins are food-borne pathogens, such as Listeria monocytogenesis and antibiotic-resistant strains of Salmonella spp., Campylobacter spp., Escherichia coli and Enterococcus spp. (Kang and Lee, 2005; Nes et al., 2007; Sit and Vederas, 2008; Svetoch et al., 2008). Therefore, bacteriocins, especially lantibiotics, have promise as antibiotics to meet the requirements of food preservation and in preventing infections from foodborne pathogens (Nes et al., 2007; Sit and Vederas, 2008). The primary bactericidal mechanism of bacteriocins is through membrane pore formation as shown for most lantibiotics. However, some bacteriocins also attack other cellular targets such as mersacidin interaction with lipid II to prevent cell-wall synthesis, microcin J25 inhibition of bacterial RNA synthesis and duramycin-C inhibition of bacterial phospholipase A2. Other bacteriocins like nisin use more than one mechanism (membrane pore formation and disruption of cell-wall synthesis) to kill targeted bacteria. The antimicrobial capacity of two-peptide bacteriocins such as Class I lacticin 3147 and Class II lactacin-F requires the combined activity of both partners to dissipate membrane potential, to induce ion leakage and/or to interfere with cellular ATP production (Fig. 1) (Cotter et al., 2005; Willey et al., 2007).

Membrane-targeting mechanisms are the most conserved killing mechanisms of AMPs identified from plants, insects and vertebrate animals (Table 1 and Fig. 1). Through their net-positive surface charge and/or amphipathic structure, AMPs undergo a pore-formation process of membrane attachment, insertion and permeabilization (Brogden, 2005). In a recently proposed two-state model based on studies of representative cysteine-rich AMPs, it is posited that AMPs initially assemble parallel to the plane of the membrane and cause membrane thinning in proportion to the peptide/lipid ratio of the membrane. As the peptides continue assembling on the membrane surface and exceed the peptide/lipid ratio threshold, the interaction enters a second state, where alignment of the peptide assemblages becomes perpendicular to the plane of the membrane and form transmembrane pores (Huang, 2006; Jang et al., 2006). Using solid-state NMR techniques, Mani et al. (2006) accurately measured the properties of 
the lytic pores induced by porcine protegrin (a cysteinerich cathelicidin) on a lipid bilayer that mimics the bacterial membrane. Although AMPs with diverse structural properties may undergo different kinetic processes, this model shows that cysteine-rich AMPs like defensins and protegrins insert a pore in the lipid bilayer through a $\beta$-barrel mechanism. In addition, due to the distinct lipid composition (mainly cholesterol content) and relative neutral charge of eukaryotic membranes compared with bacterial membranes, the effective concentration of AMPs to induce changes in eukaryotic membranes is higher than the lytic dose on bacteria (Huang, 2006; Jang et al., 2006; Mani et al., 2006). The different kinetics of AMP interaction with eukaryotic and bacterial membranes partially explain why host AMPs discriminate between host cells and bacteria. In addition, many higher vertebrates have evolved other mechanisms to target their AMPs to pathogens while limiting damage to themselves, including (i) storage of potent AMPs in special cells or cell compartments such as neutrophils and neutrophil granules (Selsted and Ouellette, 2005; Lehrer, 2007), (ii) controlled synthesis of mature AMPs only in functional organs such as synthesis of killing toxins in venom glands of arthropods, reptiles and the platypus (Warren et al., 2008), (iii) differential processing of AMP's mature peptides to balance antimicrobial activity such as multiple mature forms of human LL-37 in sweat on the skin surface (Murakami et al., 2004), and (iv) interference with AMP activity by other coexisting molecules such as serum proteins and mucins (Brogden, 2005). Similarly, bacteria also have protective mechanisms to limit harm from self-produced bacteriocins. For example, the genes for lantibiotic biosynthesis, regulation and self-immunity are found in clusters allowing for coordinated expression (Rossi et al., 2008). Furthermore, in the case of lantibiotics, immunity is provided by specific immune proteins and/or by sensing proteins to regulate bacteriocin synthesis or transport. For example, a single immune protein PepI protects Staphylococcus epidermidis from its bacteriocin Pep5 by masking the target molecule of Pep5 on the membrane. NisI, which is an outer membrane lipoprotein of Lactococcus lactis, arrests nisins to limit local concentrations from reaching the membrane of nisin-producers; however, NisI cannot protect $L$. lactis from closely related lantibiotics produced by Bacillus subtilis, indicating that self-immunity to a bacteriocin is very specific (Willey et al., 2007; Draper et al., 2008).

The overall antimicrobial effect of an AMP in vivo, which is manifested by suppression/elimination of infection by a pathogen, can result from both its direct antimicrobial activity and indirect immune regulatory functions. In this context, most AMPs in higher vertebrates, such as mammalian defensins and cathelicidins, have been shown to be multifunctional and because of this property are often referred to as host defense peptides (Hancock and Sahl, 2006; Zaiou, 2007). A partial list of these immunoregulatory functions exerted by mammalian antimicrobial host defense peptides includes chemoattractant activity for immune cells, inhibition of oxidative burst of phagocytes, promotion of angiogenesis and wound healing, regulation of development and function of male reproductive cells, and induction of autoimmunity (Hancock and Sahl, 2006; Zaiou, 2007). Although these multifunctional properties may increase the drug development potential of AMPs, some may also cause limitations in the development of antibiotics. Other challenges to AMP-based drug development include cytotoxicity and the higher cost of peptide synthesis (Hancock and Sahl, 2006; Scott et al., 2007). Finally, although microbial resistance is usually considered less likely for AMPs than conventional antibiotics, some mechanisms of resistance to AMPs have been identified (Gunn, 2008; Kraus and Peschel, 2008); this should be considered in developing and using AMP-based drugs.

Several recent publications have discussed and reviewed AMP-based drug development (Andrès and Dimarcq, 2005; Gordon et al., 2005; McPhee and Hancock, 2005; Hancock and Sahl, 2006). Most AMPbased antibiotic studies are in the discovery or preclinical stages with some proceeding to clinical trials. Nisin, a LAB lantibiotic, is one of few examples of AMP-based antibiotic therapies that have been commercialized. Other AMP-based drugs that have progressed to clinical trials, such as those derived from insect cecropin B and bovine indolicidin (Hancock and Sahl, 2006; Scott et al., 2007), have been developed to treat wounds or skin-related infections in humans, applications that may also be used in veterinary medicine. Some drugs in testing are derivatives of AMPs that have been modified to improve their antimicrobial activity. These modifications include introducing non-natural residues like D-amino acids, addition of C-terminal amidation and catalysis of cyclic formation, which are believed to improve stability and activity against targeted micro-organisms as shown in natural bacteriocins, plant cyclotides and primate $\theta$-defensins (Lehrer, 2007; Bansal et al., 2008; Ireland et al., 2008). Therefore, optimized design of synthetic peptides based on knowledge from natural AMP studies (the concept of 'designer AMPs') may provide a feasible way to increase novel drug development (Scott et al., 2007; Jenssen et al., 2008).

Generation of transgenic animals and plants by xenobiotic expression of an AMP from other species is another approach to improve disease resistance and growth performance in food animals. Transgenic animals are also potent bioreactors to produce AMP-containing prebiotics or to purify natural AMPs. For example, transgenic cows (Hyvönen et al., 2006), rabbits (Han et al., 2008) and goats (Zhang et al., 2008) expressing human lactoferrin in milk were produced to enhance health effects for dairy consumers and to provide largescale production of human lactoferrin. Although transgenic cows with xenobiotic expression of human 
lactoferrin did not exhibit enhanced protection against an E. coli intramammary infection (Hyvönen et al., 2006), transgenic mice expressing porcine lactoferrin in milk promoted offspring growth (Wu et al., 2007) and resistance to foot-and-mouth disease (Chen et al., 2008). Broiler diets containing rice that was genetically altered to express human lactoferrin or lysozyme protected chick intestinal tracts similar to subtherapeutic antibiotics and improved small intestinal architecture (Humphrey et al., 2002). Moreover, transgenic mice with ectopic expression of human intestinal defensin-5 (HD-5) (Salzman et al., 2003), porcine cathelicidin PR-39 (Lee et al., 2005) and protegrin-1 (Cheung et al., 2008) had significantly enhanced protection against enteric salmonellosis, bacterial skin infection and Actinobacillus suis infection, respectively. In contrast, transgenic mice overexpressing mouse AMPs, such as $\beta$-defensin-6 (Yamaguchi et al., 2007) or mouse cathelicidin (Lee et al., 2005), exhibited no increased resistance.

\section{Concluding remarks}

AMPs, a group of innate immune effectors with special antimicrobial mechanisms that have endured the selective pressure of years of evolution, provide an attractive platform from which to develop novel antibiotics (Beutler, 2004). The recent realization that AMPs are an essential component of microbe-host mutualism underscores the important immunoregulatory role of AMPs in addition to their well-known direct antimicrobial activity. Thus, these peptides will continue to be investigated for novel therapeutic strategies based on their multifunctional properties as antimicrobials and host defense peptides (Hancock and Sahl, 2006; Hoskin and Ramamoorthy, 2008; Steinstraesser et al., 2008).

\section{Acknowledgments}

We thank former graduate and postdoctoral students, technicians and collaborators who made this work possible and Danielle Goodband for her excellent technical support. This work was supported in part by USDA NRI Competitive Grant 2006-35204-17337.

\section{References}

Andrès E and Dimarcq JL (2005). Clinical development of antimicrobial peptides. International Journal of Antimicrobial Agents 25: 448-449.

Bansal PS, Torres AM, Crossett B, Wong KK, Koh JM, Geraghty DP, Vandenberg JI and Kuchel PW (2008). Substrate specificity of platypus venom L-to-D-peptide isomerase. Journal of Biological Chemistry 283: 8969-8975.

Barbeta BL, Marshall AT, Gillon AD, Craik DJ and Anderson MA (2008). Plant cyclotides disrupt epithelial cells in the midgut of lepidopteran larvae. Proceedings of the National Academy of Science, USA 105: 1221-1225.

Bechinger B (1997). Structure and functions of channel-forming peptides: magainins, cecropins, melittin and alamethicin. Journal of Membrane Biology 156: 197-211.

Beutler B (2004). Innate immunity: an overview. Molecular Immunology 40: 845-859.

Boman HG (2003). Antibacterial peptides: basic facts and emerging concepts. Journal of Internal Medicine 254: 197-215.

Brogden KA (2005). Antimicrobial peptides: pore formers or metabolic inhibitors in bacteria? Nature Reviews Microbiology 3: 238-250.

Chen HL, Wang LC, Chang CH, Yen CC, Cheng WT, Wu SC, Hung CM, Kuo MF and Chen CM (2008). Recombinant porcine lactoferrin expressed in the milk of transgenic mice protects neonatal mice from a lethal challenge with enterovirus type 71. Vaccine 26: 891-898.

Cheung QC, Turner PV, Song C, Wu D, Cai HY, MacInnes JI and Li J (2008). Enhanced resistance to bacterial infection in protegrin-1 transgenic mice. Antimicrobial Agents and Chemotherapy 52: 1812-1819.

Colgrave ML, Kotze AC, Huang YH, O'Grady J, Simonsen SM and Craik DJ (2008). Cyclotides: natural, circular plant peptides that possess significant activity against gastrointestinal nematode parasites of sheep. Biochemistry 47 : 5581-5589.

Cotter PD, Hill C and Ross RP (2005). Bacteriocins: developing innate immunity for food. Nature Reviews Microbiology 3: 777-788.

Crispie F, Twomey D, Flynn J, Hill C, Ross P and Meaney W (2005). The lantibiotic lacticin 3147 produced in a milkbased medium improves the efficacy of a bismuth-based teat seal in cattle deliberately infected with Staphylococcus aureus. Journal of Dairy Research 72: 159-167.

Draper LA, Ross RP, Hill C and Cotter PD (2008). Lantibiotic immunity. Current Protein and Peptide Science 9: 39-49.

Duclohier H (2007). Peptaibiotics and peptaibols: an alternative to classical antibiotics? Chemistry and Biodiversity 4: 10231026.

Dufour A, Hindré T, Haras D and Le Pennec JP (2007). The biology of lantibiotics from the lacticin 481 group is coming of age. FEMS Microbiology Reviews 31: 134-167.

De Vuyst L and Leroy F (2007). Bacteriocins from lactic acid bacteria: production, purification, and food applications. Journal of Molecular Microbiology and Biotechnology 13: 194-199.

Duquesne S, Destoumieux-Garzón D, Peduzzi J and Rebuffat S (2007). Microcins, gene-encoded antibacterial peptides from enterobacteria. Natural Product Reports 24: 708734.

Field D, Connor PM, Cotter PD, Hill C and Ross RP (2008). The generation of Nisin variants with enhanced activity against specific Gram positive pathogens. Molecular Microbiology 69: 218-230.

Ganz T (2003). Defensins: antimicrobial peptides of innate immunity. Nature Reviews Immunology 3: 710-720.

Gardiner GE, Rea MC, O'Riordan B, O'Connor P, Morgan SM, Lawlor PG, Lynch PB, Cronin M, Ross RP and Hill C (2007). Fate of the two-component lantibiotic lacticin 3147 in the gastrointestinal tract. Applied and Environmental Microbiology 73: 7103-7109.

Giacometti A, Cirioni O, Kamysz W, D'Amato G, Silvestri C, Del Prete MS, Łukasiak J and Scalise G (2003). Comparative activities of cecropin A, melittin, and cecropin A-melittin peptide $\mathrm{CA}(1-7) \mathrm{M}(2-9) \quad \mathrm{NH}_{2}$ against multidrug-resistant nosocomial isolates of Acinetobacter baumannii. Peptides 24: 1315-1318. 
Gordon YJ, Romanowski EG and McDermott AM (2005). A review of antimicrobial peptides and their therapeutic potential as anti-infective drugs. Current Eye Research 30: 505-515.

Gunn JS (2008). The Salmonella PmrAB regulon: lipopolysaccharide modifications, antimicrobial peptide resistance and more. Trends in Microbiology 16: 284-290.

Hale JD and Hancock RE (2007). Alternative mechanisms of action of cationic antimicrobial peptides on bacteria. Expert Review of Anti-infective Therapy 5: 951-959.

Hammami R, Zouhir A, Ben Hamida J and Fliss I (2007). BACTIBASE: a web-accessible database for bacteriocin characterization. BMC Microbiology 7: 89.

Han ZS, Li QW, Zhang ZY, Yu YS, Xiao B, Wu SY, Jiang ZL, Zhao $\mathrm{HW}$, Zhao R and Li J (2008). Adenoviral vector mediates high expression levels of human lactoferrin in the milk of rabbits. Journal of Microbiology and Biotechnology 18: 153159.

Hancock RE and Sahl HG (2006). Antimicrobial and host-defense peptides as new anti-infective therapeutic strategies. Nature Biotechnology 24: 1551-1557.

Hoskin DW and Ramamoorthy A (2008). Studies on anticancer activities of antimicrobial peptides. Biochimica et Biophysica Acta 1778: 357-375.

Huang HW (2006). Molecular mechanism of antimicrobial peptides: the origin of cooperativity. Biochimica et Biophysica Acta 1758: 1292-1302.

Humphrey BD, Huang N and Klasing KC (2002). Rice expressing lactoferrin and lysozyme has antibiotic-like properties when fed to chicks. Journal of Nutrition 132: 1214-1218.

Hyvönen P, Suojala L, Orro T, Haaranen J, Simola O, Røntved C and Pyörälä S (2006). Transgenic cows that produce recombinant human lactoferrin in milk are not protected from experimental Escherichia coli intramammary infection. Infection and Immunity 74: 6206-6212.

Ireland DC, Wang CK, Wilson JA, Gustafson KR and Craik DJ (2008). Cyclotides as natural anti-HIV agents. Biopolymers 90: $51-60$.

Jang H, Ma B, Woolf TB and Nussinov R (2006). Interaction of protegrin-1 with lipid bilayers: membrane thinning effect. Biophysical Journal 91: 2848-2859.

Jenssen H, Fjell CD, Cherkasov A and Hancock RE (2008). QSAR modeling and computer-aided design of antimicrobial peptides. Journal of Peptide Science 14: 110-114.

Kang JH and Lee MS (2005). Characterization of a bacteriocin produced by Enterococcus faecium GM-1 isolated from an infant. Journal of Applied Microbiology 98: 1169-1176.

Kraus D and Peschel A (2008). Staphylococcus aureus evasion of innate antimicrobial defense. Future Microbiology 3: 437451.

Kruszewska D, Sahl HG, Bierbaum G, Pag U, Hynes SO and Ljungh A (2004). Mersacidin eradicates methicillin-resistant Staphylococcus aureus (MRSA) in a mouse rhinitis model. Journal of Antimicrobial Chemotherapy 54: 648-653.

Lee PH, Ohtake T, Zaiou M, Murakami M, Rudisill JA, Lin KH and Gallo RL (2005). Expression of an additional cathelicidin antimicrobial peptide protects against bacterial skin infection. Proceedings of the National Academy of Sciences, USA 102: $3750-3755$.

Lehrer RI (2007). Multispecific myeloid defensins. Current Opinion in Hematology 14: 16-21.

Leitgeb B, Szekeres A, Manczinger L, Vágvölgyi C and Kredics L (2007). The history of alamethicin: a review of the most extensively studied peptaibol. Chemistry and Biodiversity 4: $1027-1051$.

Linde A, Ross CR, Davis EG, Dib L, Blecha F and Melgarejo T (2008). Innate immunity and host defense peptides in veterinary medicine. Journal of Veterinary Internal Medicine 22: 247-265.
Lynn DJ and Bradley DG (2007). Discovery of alpha-defensins in basal mammals. Developmental and Comparative Immunology 31: 963-967.

Mani R, Cady SD, Tang M, Waring AJ, Lehrer RI and Hong M (2006). Membrane-dependent oligomeric structure and pore formation of a beta-hairpin antimicrobial peptide in lipid bilayers from solid-state NMR. Proceedings of the National Academy of Sciences, USA 103: 16242-16247.

Marcos JF, Muñoz A, Pérez-Payá E, Misra S and López-García B (2008). Identification and rational design of novel antimicrobial peptides for plant protection. Annual Review of Phytopathology 46: 273-301.

McPhee JB and Hancock RE (2005). Function and therapeutic potential of host defence peptides. Journal of Peptide Science 11: 677-687.

Murakami M, Lopez-Garcia B, Braff M, Dorschner RA and Gallo RL (2004). Postsecretory processing generates multiple cathelicidins for enhanced topical antimicrobial defense. Journal of Immunology 172: 3070-3077.

Mygind PH, Fischer RL, Schnorr KM, Hansen MT, Sönksen CP, Ludvigsen S, Raventós D, Buskov S, Christensen B, De Maria L, Taboureau O, Yaver D, Elvig-Jørgensen SG, Sørensen MV, Christensen BE, Kjaerulff S, Frimodt-Moller N, Lehrer RI, Zasloff M and Kristensen HH (2005). Plectasin is a peptide antibiotic with therapeutic potential from a saprophytic fungus. Nature 437: 975-980.

Nes IF, Diep DB and Holo H (2007). Bacteriocin diversity in Streptococcus and Enterococcus. Journal of Bacteriology 189: 1189-1198.

Rossi LM, Rangasamy P, Zhang J, Qiu XQ and Wu GY (2008). Research advances in the development of peptide antibiotics. Journal of Pharmaceutical Sciences 97: 1060-1070.

Salzman NH, Ghosh D, Huttner KM, Paterson Y and Bevins CL (2003). Protection against enteric salmonellosis in transgenic mice expressing a human intestinal defensin. Nature 422: $522-526$.

Sang Y and Blecha F (2008). Porcine host defense peptides: expanding repertoire and functions. Developmental and Comparative Immunology, 2008 June 9 [Epub ahead of print] doi:10.1016/j.dci.2008.05.006.

Sang Y, Ortega MT, Blecha F, Prakash O and Melgarejo T (2005). Molecular cloning and characterization of three $\beta$-defensins from canine testis. Infection and Immunity 73: 2611-2620.

Sang Y, Ortega MT, Rune K, Xiau W, Zhang G, Soulages JL, Lushington GH, Fang K, Williams TD, Blecha $\mathrm{F}$ and Melgarejo T (2007). Canine cathelicidin (K9CATH): gene cloning, expression, and biochemical activity of a novel pro-myeloid antimicrobial peptide. Developmental and Comparative Immunology 31: 1278-1296.

Scott MG, Dullaghan E, Mookherjee N, Glavas N, Waldbrook M, Thompson A, Wang A, Lee K, Doria S, Hamill P, Yu JJ, Li Y, Donini O, Guarna MM, Finlay BB, North JR and Hancock RE (2007). An anti-infective peptide that selectively modulates the innate immune response. Nature Biotechnology 25: 465-472.

Selsted ME and Ouellette AJ (2005). Mammalian defensins in the antimicrobial immune response. Nature Immunology $\mathbf{6}$ : $551-557$.

Sit CS and Vederas JC (2008). Approaches to the discovery of new antibacterial agents based on bacteriocins. Biochemistry and Cell Biology 86: 116-123.

Silverstein KA, Graham MA, Paape TD and VandenBosch KA (2005). Genome organization of more than 300 defensinlike genes in Arabidopsis. Plant Physiology 138: 600-610.

Steinstraesser L, Koehler T, Jacobsen F, Daigeler A, Goertz O, Langer S, Kesting M, Steinau H, Eriksson E and Hirsch T (2008). Host defense peptides in wound healing. Molecular Medicine 14: 528-537. 
Svetoch EA, Eruslanov BV, Perelygin VV, Mitsevich EV, Mitsevich IP, Borzenkov VN, Levchuk VP, Svetoch OE, Kovalev YN, Stepanshin YG, Siragusa GR, Seal BS and Stern NJ (2008). Diverse antimicrobial killing by Enterococcus faecium E 5052 bacteriocin. Journal of Agricultural and Food Chemistry 56: 1942-1948.

Thevissen K, Kristensen HH, Thomma BP, Cammue BP and François IE (2007). Therapeutic potential of antifungal plant and insect defensins. Drug Discovery Today 12: 966971.

Warren WC, Hillier LW, Marshall Graves JA, Birney E, Ponting CP, Grützner F, Belov K, Miller W, Clarke L, Chinwalla AT, Yang S-P, Heger A, Locke DP, Miethke P, Waters PD, Veyrunes F, Fulton L, Fulton B, Graves T, Wallis J, Puente X, Lopez-Otin C, Ordonez GR, Eichler EE, Cheng LIN, Cheng ZE, Deakin JE, Alsop A, Thompson K, Kirby P, Papenfuss AT, Wakefield MJ, Olender T, Lancet D, Huttley GA, Smit Arian FA, Pask A, Temple-Smith P, Batzer MA, Walker JA, Konkel MK, Harris RS, Whittington CM, Wong ESW, Gemmell NJ, Buschiazzo E, Vargas Jentzsch IM, Merkel A, Schmitz J, Zemann A, Churakov G, Kriess JO, Brosius J, Murchison EP, Sachidanandam SC, Hannon GJ, TsendAyush E, Mcmillan D and Attenborough R (2008). Genome analysis of the platypus reveals unique signatures of evolution. Nature 453: 175-183.

Whittington CM, Papenfuss AT, Bansal P, Torres AM, Wong ES, Deakin JE, Graves T, Alsop A, Schatzkamer K, Kremitzki C, Ponting CP, Temple-Smith P, Warren WC, Kuchel PW and Belov K (2008). Defensins and the convergent evolution of platypus and reptile venom genes. Genome Research $\mathbf{1 8}$ 986-994.
Willey JM and van der Donk WA (2007). Lantibiotics: peptides of diverse structure and function. Annual Review of Microbiology 61: 477-501.

Wu SC, Chen HL, Yen CC, Kuo MF, Yang TS, Wang SR, Weng CN, Chen CM and Cheng WT (2007). Recombinant porcine lactoferrin expressed in the milk of transgenic mice enhances offspring growth performance. Journal of Agricultural and Food Chemistry 55: 4670-4677.

Yamaguchi Y, Nagase T, Tomita T, Nakamura K, Fukuhara S, Amano T, Yamamoto H, Ide Y, Suzuki M, Teramoto S, Asano T, Kangawa K, Nakagata N, Ouchi Y and Kurihara H (2007). Beta-defensin overexpression induces progressive muscle degeneration in mice. American Journal of Physiology-Cell Physiology 292: C2141-C2149.

Yeaman MR and Yount NY (2007). Unifying themes in host defence effector polypeptides. Nature Reviews Microbiology 5: 727-740.

Zaiou M (2007). Multifunctional antimicrobial peptides: therapeutic targets in several human diseases. Journal of Molecular Medicine 85: 317-329.

Zanetti M (2005). The role of cathelicidins in the innate host defenses of mammals. Current Issues in Molecular Biology 7: 179-196.

Zhang J, Li L, Cai Y, Xu X, Chen J, Wu Y, Yu H, Yu G, Liu S, Zhang A, Chen J and Cheng G (2008). Expression of active recombinant human lactoferrin in the milk of transgenic goats. Protein Expression and Purification 57: 127-135.

Zhu S (2008). Discovery of six families of fungal defensin-like peptides provides insights into origin and evolution of the CSalphabeta defensins. Molecular Immunology 45: 828838. 